\title{
Editorial: Feeding and Nutritional Strategies to Reduce Livestock Greenhouse Gas Emissions
}

\author{
Paula Toro-Mujica ${ }^{1 *}$ and Manuel González-Ronquillo ${ }^{2}$ \\ ${ }^{1}$ Instituto de Ciencias Agroalimentarias, Animales y Ambientales, Universidad de O'Higgins, San Fernando, Chile, ${ }^{2}$ Facultad \\ de Medicina Veterinaria y Zootecnia, Universidad Autónoma del Estado de México, Toluca, Mexico
}

Keywords: ruminant, tropical forage, secondary metabolites, simulation model, enteric methane mitigation

\section{Editorial on the Research Topic}

\section{Feeding and Nutritional Strategies to Reduce Livestock Greenhouse Gas Emissions}

Ruminants play a fundamental role in the world's food and the sustainability of agricultural production systems (1). The nutritional composition of their products ensures the supply of essential nutrients, including amino acids, fatty acids, vitamins, and minerals. Furthermore, the proper management of productive systems favors the conservation of the landscape and allows carbon sequestration by improving the health of the soil through the increase of organic matter (2). However, the current rate of production to which animal production systems are subjected tends to exceed their natural productive capacity. This makes it necessary to include many agricultural and veterinary inputs, breaking the production/carbon sequestration balance and polluting air, water, and soil (3). In this scenario, livestock production has been strongly questioned, among other reasons, due to the emission of greenhouse gases. Estimates indicate that greenhouse gas (GHG) production from livestock represents $14.5 \%\left(7.1 \mathrm{Gt} \mathrm{CO}_{2 \text { eq }}\right.$ annual $\left.{ }^{-1}\right)$ of total anthropogenic emissions, with enteric emissions contributing $35 \%$ of the sector's emissions (4). The reduction of GHG emissions and the adaptation to the new climate change scenarios are urgent needs in the agriculture and forestry sector. Animal feeding is one of the variables with the most significant influence on total GHG production and production efficiency (5). The latter is expressed either through traditional indicators such as the conversion rate and weight gain or through the carbon footprint. Thus, the search for comprehensive strategies to mitigate GHG emissions from livestock systems must incorporate strategies associated with animal feed and nutrition and ultimately evaluate their effect through productive parameters.

In this Research Topic, seven articles analyze and propose feed and nutritional strategies aimed at reducing GHG emissions. The studies presented by Enriquez et al., Gaviria-Uribe et al., and Su and Chen analyze the effect of incorporating forage and shrub species into ruminant's diets. Enriquez et al. study the effect of incorporating a fresh mixed annual ryegrass and berseem clover forage into the winter diet of dairy cows in intensive production systems that base feeding on a total mixed ration with a base of conserved summer crops. Gaviria-Uribe et al. evaluate the effect of the nutritional composition and voluntary intake of diets based on tropical forages upon $\mathrm{CH}_{4}$ emissions from zebu steers. The tropical forages used by Gaviria-Uribe et al. include novel Cayman grass and Leucaena shrub legumes. Through a review article, Su and Chen summarize the effects of the inclusion of Moringa oleifera leaf in broiler chickens, layers, pigs, aquatic animals, and ruminants. Moringa oleifera is commonly used for its protein content; however, its inclusion has also been related to a decrease in methane production. Therefore, the incorporation of leaves, flour, seeds, or extracts of Moringa oleifera, thanks to the natural capacity of the species to inhibit methanogenesis, has reported successful results in research carried out in buffalos (6), goats (7), beef 
cattle (8), and dairy cows (9). As Su and Chen point out, Moringa oleifera has a high concentration of secondary metabolites, which would regulate fermentation conditions and associations between microorganisms. This characteristic has also been observed in Leucaena leucocephala species in which high contents of condensed tannins are found (10).

Regarding the use in animal feeding of species with high concentrations of secondary metabolites, recent research has evaluated the incorporation of seaweed into ruminant diets with results, in some cases, promising $(11,12)$. Through his Perspective article, Vijn et al. consider the use of seaweed and provides valuable recommendations for the design of research associated with the use of seaweed as an enteric methane mitigant in the stages of seaweed production, animal feed production, and livestock production. Ku-Vera et al. perform an exhaustive review on the role of secondary plant metabolites on enteric methane mitigation, explaining the possible mechanisms of action of tannins, saponins, essential oils, flavonoids on enteric $\mathrm{CH}_{4}$ mitigation. In addition to secondary metabolites, there is a wide range of additives that have been evaluated in ruminant diets to mitigate GHG, including lipids, ionophores, nitrogen sources, and biocarbon (13-16). In the case of lipids, these are offered mainly through oil-rich seeds, such as cottonseed (17), linseed $(13,18)$, and canola oil $(16,19)$. Among ionophores, one of the most used is monensin, whose incorporation in ruminant diets has been related to increased feed conversion efficiency. The efficiency increase will be produced by decreasing gram-positive bacteria and protozoa (20). Regarding nitrogen sources in sheep (21) and cattle (22), there are examples of how the incorporation of urea or nitrates help to reduce methane

\section{REFERENCES}

1. Oltjen WJ, Beckett LJ. Role of ruminant livestock in sustainable agricultural systems. J Anim Sci. (1996) 74:1406-9. doi: 10.2527/1996.7461406x

2. Brewer MK, Gaudin MCA. Potential of crop-livestock integration to enhance carbon sequestration and agroecosystem functioning in semi-arid croplands. Soil Biol Biochem. (2020) 149:107936. doi: 10.1016/j.soilbio.2020.107936

3. Garrett RD, Niles MT, Gil JDB, Gaudin A, Chaplin-Kramer R, Assmann A, et al. Social and ecological analysis of commercial integrated crop livestock systems: current knowledge and remaining uncertainty. Agri Syst. (2017) 155:136-46. doi: 10.1016/j.agsy.2017.05.003

4. Gerber P, Steinfeld H, Henderson B, Mottet A, Opio C, Dijkman J, et al. Tackling Climate Change through Livestock-A Global Assessment of Emissions and Mitigation Opportunities. Rome: Food and Agriculture Organization (2013). Available online at: http://www.fao.org/3/a-i3437e.pdf (accessed May 5, 2021).

5. Hristov AN, Oh J, Firkins JL, Dijkstra J, Kebreab E, Waghorn G, et al. SPECIAL TOPICS - Mitigation of methane and nitrous oxide emissions from animal operations: I. A review of enteric methane mitigation options. J Anim Sci. (2013) 91:5045-69. doi: 10.2527/jas.2013-6583

6. Abdel-Raheem MS, Hassan HE. Effects of dietary inclusion of Moringa oleifera leaf meal on nutrient digestibility, rumen fermentation, ruminal enzyme activities and growth performance of buffalo calves. Saudi J Biol Sci. (2021) 4:37. doi: 10.1016/j.sjbs.2021.04.037

7. Kholif AE, Gouda GA, Anele UY, Galyean LM. Extract of Moringa oleifera leaves improves feed utilization of lactating Nubian goats. Small Ruminant Res. (2018) 158:69-75. doi: 10.1016/j.smallrumres.2017.10.014

8. Lins JOTDA, Terry SA, Silva RR, Pereira LGR, Jancewicz LJ, He ML, et al. Effects of the inclusion of Moringa oleifera seed on rumen fermentation and emissions. Studies on the effects on methane emissions of the inclusion of biocarbon in ruminant diets are still scarce, due to this, Terry et al. analyze the effect of the inclusion of the pine enhanced biochar (EB) in heifer diets on various parameters associated with ruminal fermentation, including methane $\left(\mathrm{CH}_{4}\right)$ emissions. Finally, Toro-Mujica, using the results of previous research about the effect of the use of additives in the production of GHG, raises the need for evaluation at the livestock system level. With this objective, using a simulation model, Toro-Mujica determines the effect of modifying management practices and incorporating two additives (monensin and canola oil) into the diet on bio-economic variables and carbon footprint of cow-calf systems.

Considering the current climate change scenario, this Research Topic contributes to the knowledge of feed and nutritional strategies for the mitigation of livestock greenhouse gas emissions, and their evaluation at the production system level.

\section{AUTHOR CONTRIBUTIONS}

PT-M wrote the first draft. MG-R wrote and edited the second draft. All authors contributed to the article and approved the submitted version.

\section{FUNDING}

This work was supported by Comisión Nacional de Ciencia y Tecnología (CONICYT, Chile) through the project FONDECYT11190367. methane production in a beef cattle diet using the rumen simulation technique (Rusitec). Animal. (2019) 13:283-91. doi: 10.1017/S1751731118001428

9. Dong L, Zhang T, Diao Q. Effect of dietary supplementation of Moringa oleifera on the production performance and fecal methanogenic community of lactating dairy cows. Animals. (2019) 9:262. doi: 10.3390/ani9050262

10. Tan HY, Sieo CC, Abdullah N, Liang JB, Huang XD, Ho W, et al. Effects of condensed tannins from Leucaena on methane production, rumen fermentation and populations of methanogens and protozoa in vitro. Anim Feed Sci Technol. (2011) 169:185-93. doi: 10.1016/j.anifeedsci.2011.07.004

11. Dubois B, Tomkins NW, Kinley RD, Bai SSM, Paul RDNNA. Effect of tropical algae as additives on rumen in vitro gas production and fermentation characteristics. Am J Plant Sci. (2013) 4:34-43. doi: 10.4236/ajps.2013.412A2005

12. Kinley RD, Martinez-Fernandez G, Matthews MK, de Nys R, Magnusson M, Tomkins W, et al. Mitigating the carbon footprint and improving productivity of ruminant livestock agriculture using a red seaweed. J Clean Prod. (2020) 259:120836. doi: 10.1016/j.jclepro.2020.120836

13. Ponce $\mathrm{CH}$, Smith DR, Branine ME, Hubbert ME, Galyean LM. Effects of type of ionophore and carrier on in vitro ruminal dry matter disappearance, gas production, and fermentation end products of a concentrate substrate. Anim Feed Sci Technol. (2012) 171:223-9. doi: 10.1016/j.anifeedsci.2011.11.003

14. Tomkins NW, Denman SE, Pilajun R, Wanapat M, McSweeney CS, Elliott R. Manipulating rumen fermentation and methanogenesis using an essential oil and monensin in beef cattle fed a tropical grass hay. Anim Feed Sci Technol. (2015) 200:25-34. doi: 10.1016/j.anifeedsci.2014.11.013

15. Saleem AM, Ribeiro GO Jr, Yang WZ, Ran T, Beauchemin KA, McGeough EJ, et al. Effect of engineered biocarbon on rumen fermentation, microbial protein synthesis, and methane production in an artificial rumen (RUSITEC) fed a high forage diet. J Anim Sci. (2018) 96:3121-30. doi: 10.1093/jas/sky204 
16. Villar ML, Hegarty RS, Nolan JV, Godwin IR, McPhee M. The effect of dietary nitrate and canola oil alone or in combination on fermentation, digesta kinetics and methane emissions from cattle. Anim Feed Sci Technol. (2020) 259:114294. doi: 10.1016/j.anifeedsci.2019.114294

17. Beck MR, Thompson LR, White JE, Williams GD, Place SE, Moffet CA, et al. Whole cottonseed supplementation improves performance and reduces methane emission intensity of grazing beef steers11Mention of trade names or commercial products in this article is solely for the purpose of providing specific information and does not imply recommendation or endorsement by the USDA. The USDA prohibits discrimination in all its programs and activities on the basis of race, color, national origin, age, disability, and where applicable, sex, marital status, familial status, parental status, religion, sexual orientation, genetic information, political beliefs, reprisal, or because all or part of an individual's income is derived from any public assistance program. Professional Anim Scientist. (2018) 34:339-45. doi: 10.15232/pas.2018-01722

18. Doreau M, Arbre M, Popova M, Rochette Y, Martin C. Linseed plus nitrate in the diet for fattening bulls: effects on methane emission, animal health and residues in offal. Animal. (2018) 12:501-7. doi: 10.1017/S1751731117002014

19. Pinares-Patiño CS, Franco FE, Molano G, Kjestrup H, Sandoval E, MacLean S, et al. Feed intake and methane emissions from cattle grazing pasture sprayed with canola oil. Livest Sci. (2016) 184:7-12. doi: 10.1016/j.livsci.2015.11.020

20. Witzig M, Zeder M, Rodehutscord M. Effect of the ionophore monensin and tannin extracts supplemented to grass silage on populations of ruminal cellulolytics and methanogens in vitro. Anaerobe. (2018) 50:4454. doi: 10.1016/j.anaerobe.2018.01.012

21. Adejoro FA, Hassen A, Akanmu AM, Morgavi PD. Replacing urea with nitrate as a non-protein nitrogen source increases lambs' growth and reduces methane production, whereas acacia tannin has no effect. Anim Feed Sci Technol. (2020) 259:114360. doi: 10.1016/j.anifeedsci.2019.114360

22. van Wyngaard JDV, Meeske R, Erasmus LJ. Effect of dietary nitrate on enteric methane emissions, production performance and rumen fermentation of dairy cows grazing ryegrass pasture during spring. Anim Feed Sci Technol. (2019) 252:64-73. doi: 10.1016/j.anifeedsci.2019. 04.006

Conflict of Interest: The authors declare that the research was conducted in the absence of any commercial or financial relationships that could be construed as a potential conflict of interest.

Copyright (c) 2021 Toro-Mujica and González-Ronquillo. This is an open-access article distributed under the terms of the Creative Commons Attribution License (CC $B Y)$. The use, distribution or reproduction in other forums is permitted, provided the original author(s) and the copyright owner(s) are credited and that the original publication in this journal is cited, in accordance with accepted academic practice. No use, distribution or reproduction is permitted which does not comply with these terms. 